\title{
Marginality in Literary Discourses: Conversations with the Dead in Rabisankar Bal's Dozakhnama
}

Dr Dhurjjati Sarma ${ }^{\dagger}$

\section{Abstract}

Rabisankar Bal's Bengali novel Dozakhnama: Conversations in Hell (translated into English and published in 2012) is an imaginative biography of Mirza Ghalib (1797-1869), and Saadat Hasan Manto (1912-1955) recreated through their conversations from their respective graves. The narrative is enmeshed with the respective historical periods inhabited by the two writers, the first war of Indian independence in 1857 and the Partition in 1947 respectively. It is as if Ghalib bares his heart out to Manto from his grave, while the latter in turn realises that his life too has witnessed a similar kind of socio-cultural and literary marginalisation that destiny determined for both of them. The 'narrator' pieces together the traces left behind by the dead themselves and thereby constructs a compelling narrative that resonates in the larger literary and cultural life of India, along with the associated marginalisation of history, politics, and linguistic identities of their times. This study undertakes a comparative examination of the 'lives' of both Manto and Ghalib as recreated in the novel through the textual traces left behind by the persons themselves.

Keywords: Identity; Marginality; Memory; Ghalib; Manto

\footnotetext{
${ }^{\dagger}$ Assistant Professor, Department of Modern Indian Languages and Literary Studies, Gauhati University, Assam, India Email: dhurjjati.sarma@gmail.com

(C) 2020 Sarma. This is an Open Access article distributed under the terms of the Creative Commons Attribution License (http://creativecommons.org/licenses/by/2.0), which permits unrestricted use, distribution, and reproduction in any medium, provided the original work is properly cited.
} 


\section{Introduction}

Dozakhnama: Conversations in Hell, a novel by Rabisankar Bal, originally published in Bengali (2010) and subsequently translated into English (2012) and Hindi (2015), tells the story of two doyens of Urdu literature, Mirza Ghalib and Saadat Hasan Manto, in their own words as they are depicted as conversing with each other from their respective graves. However, the narrative structure is constructed through multiple layers of meaning and signification, and the agency of interpretation keeps shifting vigorously throughout the novel. This polyphony is characterised not only by the juxtaposition of multiple voices located in specific spatialtemporal zones across historical time but also reflective of the anxiety and restlessness of the milieu that provided the context for these voices to emerge and engage in conversations.

On a mission to conduct research on the tawaaifs (courtesans) of Lucknow, the novel's narrator (who is, by profession, a journalist) meets a person called Farid Mian who hands over an unpublished manuscript to him which, he claims, is a 'dastan' composed by Saadat Hasan Manto on the life of Mirza Ghalib. Farid Mian expresses his inability to carry forth the burden of the narrative any further and, therefore, requests the narrator to get it published. The 'dastan' is composed in Urdu, and, since the narrator has no knowledge of the language, he undertakes to get it translated with the help of a friend. Interestingly, right from the very beginning of the novel, from the first chapter where the narrator talks about the chain of events that eventually leads him to lay his hands upon the 'dastan', there is a terrifying consciousness of inevitability, of life and death, and thereby the necessity of stories to be narrated and preserved for posterity. The stories pieced together constitute the imaginative biography of Mirza Ghalib and Saadat Hasan Manto whose lives were entangled with the respective historical periods inhabited by the two writers. The traces left behind by the dead are juxtaposed to create a compelling narrative that resonates in the larger literary and cultural life of India, along with the associated marginalisation of history, politics, and linguistic identities.

\section{Background and Objectives}

If the first war of Indian independence in $1857^{1}$ signified an abrupt halt to the tradition of storytelling and the 'dastangos' (storytellers) along the streets and corridors of Delhi, then the Partition in $1947^{2}$ too caused irreparable damages to a million lives of the country. Ghalib and Manto were the respective inhabitants of the two worlds mentioned above whose lives were subjected to untold miseries and humiliations. It is as if Ghalib bares his heart out to Manto from his grave, while the latter in turn realises that his life too has witnessed a similar kind of socio-cultural and literary marginalisation that destiny determined for both of them. Therefore, this 'novel' actually becomes a discursive narrative where a dead person attempts to converse with another dead person who lived and died a century earlier.

This study undertakes a comparative examination of the 'lives' of both Manto and Ghalib recreated through the textual traces left behind by the persons themselves. I would try to argue that, by unravelling the textures of the life of the dead and trying to hear the dead speak, the narrator of Dozakhnama ends up hearing the marginal voices of his own times. The life of the narrator, of Manto, and of Ghalib gets enmeshed

\footnotetext{
1 "Indian Mutiny, also called Sepoy Mutiny or First War of Independence, widespread but unsuccessful rebellion against British rule in India in 1857-59. Begun in Meerut by Indian troops (sepoys) in the service of the British East India Company, it spread to Delhi, Agra, Kanpur, and Lucknow. In India it is often called the First War of Independence and other similar names." (The Editors of Encyclopaedia Britannica, 2020)

2 "In August 1947, British India won its independence from the British and split into two new states that would rule themselves. The new countries were India and Pakistan. East Pakistan has since become Bangladesh." ("The Partition of India: What happened?", 2018)
} 
with one another, and what we readers hear is a medley of muddled and hitherto unheard voices.

\section{Marginality in Life and Literature: The Case of Ghalib and Manto}

In his essay entitled "Defining Marginality?", Jonathan Crewe (1991, p. 121) claims that, "the discourse of the marginal is not governed by any single, pure, or abstract logic. The very term 'logic' is suspect in this context on account of its logocentric taint, and every case of the marginal is a complex special case." Likewise, the lives of Ghalib and Manto, as being 'marginal', cannot be reduced to mere plausibilities of withdrawal and suppression, also given the fact that both of them are now idolised as canonical figures of modern Urdu literary culture. The marginal positions of these litterrateurs should be assessed from the vicissitudes of historical events within which they found themselves entangled and against which they fought all their lives. In other words, the 'marginality' of both Ghalib and Manto constitutes in them being 'perpetual non-conformists', however also accompanied by marked differences between them in the manner in which they 'fashioned' their own 'special' identities. The novelist of Dozakhnama has, as we shall see, skilfully negotiated between the double tasks of showing, on the one hand, the 'twinned' fortunes of the two real-life characters tied to the history of the nation, and, on the other hand, make them stand out as distinct personas, each idiosyncratic and eccentric in their own ways.

Furthermore, a crucial point that would be explored in the course of this present study is concerning the location of both Ghalib and Manto on the periphery together with those who have been neglected by history. By internalising the sensibilities of those forgotten characters and telling their stories, it could be argued that both of them ended up integrating their own destinies with them. It was as if they chose to live the life of their own characters, with all the attendant agonies and anxieties, articulated in cacophonic and discordant voices. In the spirit of what Crewe rightly pointed out above, we can similarly argue that there can be no 'logic' as well in finding out a 'method' in the madness, especially, the one that characterised the times both our characters lived in. Therefore, 'marginality', in this context, is defined not merely by what stood in opposition to what is 'central' or 'official', but actually by what is articulated through a multiplicity of conflicting voices, including those of the 'dead', as is the subject-matter of the novel under discussion here. The onus is on the readers to navigate through the dark and labyrinthine alleys of memory and history in order to comprehend the complexities of the narrative.

\section{Discussion}

In a somewhat similar book called Will in the World: How Shakespeare Became Shakespeare, the author Stephen Greenblatt, in the Preface, hints towards a possible way to decode the mystery surrounding the life and works of William Shakespeare. He says:

To understand who Shakespeare was, it is important to follow the verbal traces he left behind back into the life he lived and into the world to which he was so open. And to understand how Shakespeare used his imagination to transform his life into his art, it is important to use our own imagination. (Greenblatt, 2005, p. 14)

In this book, Greenblatt places together the extant traces and fragments of Shakespeare's life and whatever evidence that could be gleaned from the poems and plays composed by him in order to write a compelling biographical narrative and, as remarked by David Walton of St. Petersburg Times, undertake "one of the most persuasive reconstructions of Shakespeare's life and career" (quoted in Greenblatt, 2005, p. 2). In an earlier book Shakespearean Negotiations: The Circulation of Social Energy in Renaissance England (1988), Greenblatt had made his intentions amply, though a bit morbidly, clear that he intended to speak with the dead. And in his attempt to recreate a conversation with them, he said: "I could hear only my own voice, but my own voice was the voice of the dead, for the dead had contrived to leave textual traces of themselves, 
and those traces make themselves heard in the voices of the living" (Greenblatt, 1988, p. 1).

In the case of Dozakhnama too, the author-cumnarrator reveals a similar experience of coming across someone from the other world, when he says:

Wandering aimlessly on the streets, if you happen to spot someone whom you do not expect to see except in a dream or in a picture, if you actually come face to face with them for a moment, what will you conclude? Will you not feel as though a door has been opened intriguingly for you? (Bal, 2012, p. 1)

Therefore, considering Greenblatt's formulation with respect to Shakespeare and the recovery of his 'dead' voice, we may similarly argue that the narrator in Dozakhnama too embarks upon a quest to recover the lost lives of both Ghalib and Manto, however, with the difference that both of them are made to narrate their own stories and thereby make sense of their own marginalities.

While for Greenblatt, his intention of reconstructing the life of Shakespeare as a biographical narrative is pretty clear from the outset, the narrator in Dozakhnama is gradually led through a series of events when he supposedly embarks on the translation of the aforementioned novel about Mirza Ghalib written by Manto in the style of a 'dastan'. What makes this narrative more intriguing than that of Greenblatt's is a constant shifting of the narrative agency from Manto to Ghalib and vice versa. While for Ghalib, it is his plight to recollect all that he has gone through from the childhood onwards to Manto; for the latter, it is doubly disconcerting to learn what his mentor had endured coupled with the knowledge of his distress which he shares with the former. And through these interspersed narratives, what we readers acquire is panoramic picture of the life of Delhi, and by extension, the whole of north India, across a hundred years from the time of the revolt of 1857 to the Partition of the country in 1947 and a few years thereafter.
Talking about Ghalib, Manto confesses that: "I've always felt that Mirza and I are two mirrors facing each other.Within both the mirrors is an emptiness. Two voids staring at each other. Can voids have a dialogue between themselves?" (Bal, 2012, p. 14). As evident from the stories that they tell each other, both Ghalib and Manto have throughout their lives fought with a sense of emptiness that pervaded the private and public spheres of their lives alike. Interestingly, the introduction bears the date - January 18, 1955 - beneath Manto's signature, which is incidentally the date on which Manto died. While for the narrator, this means that the 'dastan' he is planning to translate has not actually been composed by Manto, but by someone else claiming to be him. However, it is essential to recognise the fact that this 'dastan' is effectively a conversation between two deceased persons and to be one of them, Manto has first of all to meet his own death. And it is in death that both of them find succour away from the tumultuous events of life outside their graves. Fame and success have eluded them throughout their lives, and interestingly, Ghalib equates his fortune with that of Shahjahanabad upon which stands Delhi as we know now. Ghalib says:

This is a city whose story is told in regret - it was born of sorrow, it died of sorrow. I have seen this death, Manto bhai, I will recount every bit of what I saw. I must. For this city is my flesh and my bones. I'm not exaggerating, Chandni Chowk was my backbone, the Qila-e-Mualla, the Red Fort, was my misshapen skull. And my heart? That was Jama Masjid ... It was in the courtyard of the Jama Masjid that I first heard Khwaja Moinuddin Chishti tell stories. (Bal, 2012, p. 90)

Considering the fact that Ghalib is lying buried in Delhi, in a graveyard near Hazrat Nizamuddin Auliya Dargah, he is at one with the buried remnants of the past cities, including Shahjahanabad, beneath the surface upon which the Delhi of Ghalib's lifetime was built. With his death, Ghalib has retreated to the past, back to Shahjahanabad, back to the days of Khawaja 
Moinuddin Chisti, thereby escaping out from the clutches of history that only talks about the vanquisher, not the vanquished. Ghalib tells Manto: "I grew up listening to stories, Manto bhai, could history possibly show me the way to heaven? On the contrary, we have been burnt to cinders in the hell of history ever since 1857" (Bal, 2012, pp. 91-92).

Ghalib claims that the day he arrived in Shahjahanabad, he was accosted by the ones whom history does not write about. They had been buried alive in order to build Shahjahanabad. Ghalib recounts his first experience of Shahjahanabad:

I was standing before the Qilla-e-Mualla after my arrival in Dilli. There was no moon in the sky; the fortress appeared to be a gigantic ghost. And I felt people gathering around me, their breaths rank with the stench of rotting flesh. (Bal, 2012, p. 94)

Voices coming from the dead, in this way, remain a recurring phenomenon throughout the narrative. It is as if the dead ones are still lurking along the margins of history and struggling to make themselves heard. Once dead, both Ghalib and Manto become the spokesperson representing not only the dead souls, but also the $a d a b$ and tehzeeb of a culture relegated to the periphery after the revolt of 1857 and finally dealt a death blow with the Partition in 1947.

By the eighteenth century, 'Urdu' came to be identified with the language used in and around the city of Delhi, and it continued till the early part of the nineteenth century when the British government superseded Persian as the official language of administration with English at the higher levels of governance and the vernaculars at the provincial levels. Moreover, the eventual decision in favour of Anglicist model of education over the existing Oriental model further led to the relegation of classical languages, among them Persian as well as Sanskrit and Arabic, as subjects of lesser importance as far as government patronage was concerned. As a consequence, the population across large parts of Bihar, the North-Western Provinces, Oudh and Punjab learned Urdu. In fact, Urdu soon became a language of the intelligentsia as well as the lay public of north India in the nineteenth century. However, the period also marked a distinctive change in the Urdu literary sensibility of the time brought about due to the decline of the aristocratic class and the rise of British power at the end of the failed war of 1857 . These caused a gradual shift away from poetry, manifested gloriously in the genre of the ghazal, towards the development of a prose genre accompanied by a supposedly chaste idiom. This move from poetry to prose has also been seen as a movement from romantic sentiment to realism, from elitism within a courtly culture to a democratic sensibility in the public sphere, from the pursuit of pleasure to the rigours of self-discipline, and, most importantly, from Urdu to Hindi (Faruqi, 2001; Shingavi, 2016, p. 145).

For Ghalib and his generation of poets, this movement had disastrous consequences, since they were not only robbed of whatever patronage they had been receiving at the court of the Mughal king, the new colonial dispensation was largely unmindful of their intellectual pursuits. It is no wonder that post1857 , Ghalib spent the last twelve years of his life in relative silence and obscurity, as is evident from his words of lamentation addressed to Manto:

It is true that I lived another twelve years after 1857, but I did not care to talk to anyone. But still I had to speak, for selling words was my livelihood. But other than what was absolutely necessary to earn a living, speech had become haraam to me, it was profane. (Bal, 2012, p. 26)

Referring to the culture of story-telling in preBritish Delhi, he says,

These dastangos are strange people. They spent the entire day in the courtyard of the mosque, telling their stories - that was how they made their living.... Our era was nothing but a fabric woven with the thread of stories, Manto bhai.... The British, the goras, took over Dilli after the sepoys rose in mutiny, those were terrible times, Manto bhai, all 
of Dilli seemed to have become a Karbala, and the dastangos were lost forever too. There was no room for stories anymore in the Englishman's Dilli; as you know, the goras don't want fiction, they want history. (Bal, 2012, p. 31)

The fading away of the dastangos was an indication of a gradual diminishment of a culture that emphasised upon stories and oral storytelling as integral components of social-cultural imagination of the people.

The very fact that stories, including myths and legends, however impractical they might have seemed to the goras as Ghalib would say, have remained the mainstay of the Indian imagination. In the year 1827, Ghalib left Shahjahanabad in the search of better employment opportunities in Calcutta, and on the way stopped over at Kashi which seemed to be "the entire world" for him, as "compris[ing] [the] very pilgrim spot and every drop of sacred water in India" (Bal, 2012, p. 234). Reiterating his preoccupation with death as has been manifest throughout the novel, Ghalib states that, "[m]oreover, only if we die in Kashi are we released from the cycle of rebirth" (Bal, 2012, p. 235). And once again, the importance of stories to our existence is emphasised as he claims, "[o]nly in our country is it said that even listening to a story of good deeds can mitigate your sins" (Bal, 2012). And the inseparable connection between death and stories about life is further strengthened when he asserts that:

No account of Kashi can be complete without telling you of what lies on the other side of death, which is desire. Desire is not just for the woman's body, it exists in music and dance and in the very touch and fragrance of the air, in everything. Our lust and longing have so many stories about them. (Bal, 2012, pp. 236-237)

Again, breaking away from the clutches of history, Ghalib, sitting at the Manikarnika Ghat and enamoured of the sights and fragrance of Kashi, comes across the shadowy figure of Kabir as the latter, seated at a distance, is humming a mournful song 'charkha chale surat birhan ka'. Kabir is described as a "lean man dressed in nothing but a loincloth, and beads around his neck" (Bal, 2012, p. 258). It is in the words of Kabir that Ghalib seems to have found solace in the midst of the drudgeries of the world and even declares to Kabir that he does not want to go any farther than Kashi. But Kabir instructs him to continue his journey:

You must travel along the road that life has opened up before you. No matter how much the suffering and the deprivation on this road, you cannot deny the path that the lord has ordained for you. Who else will travel on your road if not you? (Bal, 2012, p. 264)

This 'fictional' encounter with Kabir not only provides Ghalib with a new vision for his life ahead, but also makes him realise through a number of stories that the only way to remain content in life, whether in happiness and sorrow, is by reiterating to oneself that "[t]his too shall pass". Now that Ghalib is dead and content in his grave, away from the trials and tribulations of life, this message is all the more edifying and therapeutic to him. He seems to have learnt his lessons of life even though life continued to be hostile to him even after his return from Calcutta.

For Manto, listening to Ghalib re-emphasises the fact that there were no lessons learnt from the disaster of 1857 . He remains convinced that the only truth is that of death - death of people, death of a civilisation. The continuity from 1857 to 1947 is aptly summarised by Manto himself when he tells Ghalib:

There's so much we cannot remember even when alive, and death comes down like a curtain, behind which you can see nothing. In 1947, I saw how the curtain of death wipes out everything. By the grace of God you did not have to see this. You saw 1857. But if you had seen 1947, Mirza sahib, you would have killed yourself. Or, perhaps, the sword would have flashed in your hand, too, as it did in your ancestors'. The world has never seen so much killing, so many rapes, such 
treachery, all of which began in 1947 on the pretext of there being two nations; today, you lie in a grave in one of those countries, and $\mathrm{I}$, in a grave in the other. (Bal, 2012, p. 20)

In his stories, Manto depicted this violence in raw and unabashed fashion, and for this, he had to appear at court more than once defending against charges of obscenity. Most of his stories were those concerning women whom he claimed to have seen standing for customers in Amritsar's Kachha Ghania, in Lahore's Hira Mandi, on Delhi's GB Road, on Bombay's Foras Road. He strove to tell their stories, the stories of their flesh, the stories of their hearts, the stories of the blood and sweat and the toils and tears endured by these real-life personas whose stories were in search of Manto for years altogether and deserved to be narrated in the true-to-life style. As Manto laments: "No one was willing to believe those stories; they accused me of making them up. I was called a whore's writer, a pornographer, because I wrote about them. But how could I remain silent, Mirza sahib?" (Bal, 2012, p. 23).

In a self-questioning gesture, Manto also confronted his own affectations; unlike Ghalib who had a high sense of self-esteem, Manto was ruthless in self-criticism as he was in assessing other personas around him. He asks himself: "All of Hindustan will reek with the stench of your stories. You bastard, you swine, you dare write Thanda Gosht? Is there no limit to your defiance of our religion?" (Bal, 2012, p. 103). However, soon after, he asserts,

[I]f you must discover Manto, read his stories - all those men and women you see, on the streets, in the slums, at the whorehouses, in the movie studios of Bombay - you might just find Manto among them. Are these stories or shit, they would ask. For heaven's sake, if you can't understand the times we live in, read my stories, and if you cannot bear to read them you'll know that you cannot bear to live in these times. (Bal, 2012, pp. 103-104)
Like one of his characters, Toba Tek Singh, Manto saw himself standing upon a piece of no man's land or rather a liminal space from where he sought to cleanse the dirt of the society he lived in. However, nobody, apart from his characters, could understand him, not even God as he claims in the mock obituary that he wrote for himself:

Here lies Saadat Hasan Manto in eternal rest. With him have been buried all the mysteries of writing stories. Under tons of earth he lies, wondering who among the two is the greatest writer of stories Allah or He. (Bal, 2012, p. 15)

It is no wonder that he quotes his wife Shafia telling him once that, "[i]f you weren't a writer, Manto sahib, our lives would not have been ruined this way" (Bal, 2012, p. 279). However, there was no option either for Manto or his mentor Ghalib apart from writing to fend for themselves in the respective periods of darkness that they endured. As Ghalib notes,

With the centuries-old empire now a rotting corpse, while the concealed daggers were clearly visible in the belts of those who had arrived as harbingers of civilisation, what else was there to do besides paying homage to the corpse with an array of words? I began to write Dastambu. I would have to write all that I could see and hear, all that was happening around me, in Farsi prose. I named this bloody chapter Dastambu - $A$ Bouquet of Flowers. (Bal, 2012, p. 453)

However, this very example of dazzling Farsi prose was, as Ghalib himself confesses, also 'a document of betrayal' for he "painted a picture of a period of nightmares, but to save [himself] [he] also sold the picture to the foreign empire" (Bal, 2012, p. 460).

Similarly, Manto responded to the grim realities around him in Bombay by penning down stories of bald angels, which he called Ganjay Farishtay. According to Manto,

Most of them were people from Bombay's world of cinema. Life was not the way it was depicted on the screen. 
Reality is not as neatly organised as films, after all. Life is another name for the war for bread, women, and power. Every story in the world is about this war. (Bal, 2012, p. 390)

And like Ghalib, Manto too harboured a fascination for Kabir as he too witnesses the weaver-poet walking the streets of Lahore, wandering about the lanes and bylanes of the city, weeping. Manto reasons that, "Kabir could have gone wherever he pleased; if Mirza sahib could have met him at the Manikarnika Ghat, why should he not have walked the streets of Lahore?" (Bal, 2012, pp. 471-472).

\section{Conclusion and Implications}

While Ghalib's life ended after twelve years of hardship and obscurity in 1869, Manto too lived the remaining years of his life after Partition in Pakistan until he died in 1955. It was as if both of them stayed eclipsed from public memory engineered respectively by the new dispensations of the British state and the postIndependence Indian state. Interestingly, both their destinies were somehow also entwined with the fate of Urdu, once the most popular language of Hindustan, in twentieth-century India. As poignantly remarked by Alok Rai (200809, p. 277):

Urdu - in its higher and lower registers is a huge civilizational achievement, one of the crown jewels of North Indian culture - along with the huge reservoir of bhakti poetry which, in Braj and Avadhi, in music and out of it, swept across practically the whole of India.

The banishment of Urdu as a 'foreign language' in post-Independence India resulted in the gradual marginalisation, or rather the effacement, of the aura and ethos associated with Urdu, and by extension, the larger Hindustani literary culture of north India.

By invoking the presence of figures like Khwaja Moinuddin Chishti and Kabir, social-cultural representatives of the glorious medieval period of north Indian history, and emphasising upon the continuance of their legacy through latterday littérateurs like Ghalib and Manto, the novelist Rabisankar Bal, in the spirit of Greenblatt, recognises the need to continue retracing the verbal footprints left behind by the personalities of the long-lost times. Often in the absence of empirical historical evidence regarding their lives, what we have with us are stories about them; our job is to listen to them attentively as they are stories of our own destinies. The novel Dozakhnama is an attempt to recover and retell those stories, even those told from the silence of the graves. It is therefore not merely a tale that endeavours to build a spatial-temporal bridge connecting two significant personalities of modern India and the troubled times that they lived in, but also a commentary on, preferably a foreboding of, the eventual fate awaiting a society or a community that neglects its past, not the past as recorded by the historian based on tangible evidence, but the one latent in the collective consciousness of the people made manifest by the stories that have endured the ravages of time. We ignore them at our own peril.

\section{References}

Bal, Rabisankar. (2012). Dozakhnama:

Conversations in hell. Trans. Arunava Sinha.

Gurgaon: Penguin Random House India Pvt. Ltd.

Crewe, Jonathan. (1991). Defining marginality?

Tulsa Studies in Women's Literature, 10(1,

Redefining marginality), 121-130. DOI:

$10.2307 / 463956$

https://www.jstor.org/stable/463956

Faruqi, Shamsur Rahman. (2001). Early Urdu

literary culture and history. Delhi: Oxford

University Press.

Greenblatt, Stephen. (1988). Shakespearean negotiations: The circulation of social energy in Renaissance England. Berkeley and Los Angeles: University of California Press.

Greenblatt, Stephen. (2005). Will in the world: How Shakespeare became Shakespeare. New York and London: W.W. Norton \& Company.

Rai, Alok. (2008-09). Longing for Urdu. India International Centre Quarterly, 35(3/4, the Great Divide), 274-281. http://www.jstor.org/stable/23006266 
Shingavi, Snehal. (2016). Premchand and the politics of language: On translation, cultural nationalism and irony. In M. Asaduddin (ed.), Premchand in world languages: Translation, reception and cinematic representations ( $\mathrm{pp}$. 144-160). London and New York: Routledge.

The Editors of Encyclopaedia Britannica. (2020, May 4). Indian Mutiny.

https://www.britannica.com/event/IndianMutiny
The partition of India: What happened?. Newsround. (2018, December 6).

https://www.bbc.co.uk/newsround/46428985

\section{Acknowledgement}

A preliminary version of this study was presented as a paper at the IACLALS Annual Conference 2020 on 'Reimagi(ni)ng Identities in the Global South: Challenges, Transgressions and Articulation' co-hosted by the Department of English, Jadavpur University, on 5-7 February 2020. 